Sains Malaysiana 49(8)(2020): 1819-1827

http://dx.doi.org/10.17576/jsm-2020-4908-06

\title{
On-Farm Epidemiological Surveillance of Genetically Improved Farmed Tilapia (GIFT) Cultured at Floating Net Cages in Pahang, Malaysia
}

(Pengawasan Epidemiologi di Ladang Ternakan Tilapia (GIFT) yang Ditingkatkan Secara Genetik pada Sangkar Ikan Terapung di Pahang, Malaysia)

\author{
Mohd Syafiq Mohammad Ridzuan*, Nur Amirah Md Radzi, Fahmi Sudirwan, Kamisa Ahmad, Kua \\ Beng Chu, Chadag Vishnumurthy MOHAN \& MOHD Firdaus NAWI
}

\begin{abstract}
Incidence of streptococcosis, parasitic infestation and Tilapia Lake Virus (TiLV) outbreaks in tilapia aquaculture were reported worldwide, affecting the production and poses a significant threat to sustainable aquaculture. There is limited information on genetically improved farmed tilapia (GIFT) strain with regard to its susceptibility against these diseases. Thus, eight months of farm-level epidemiology surveillance was conducted at a private tilapia farm from August 2017 to March 2018, to determine the prevalence of bacterial, parasite and TiLV in GIFT cage-culture. Throughout the study, a total of 205 tilapias were sampled and subjected to bacteriology, parasitology, and TiLV detection. Water quality parameters, fish weight and length, and associated clinical signs were noted. Mortality of cultured GIFT was recorded at 24.8\% from initial stocking, where high mortality was observed in early four months of the culture period. Low prevalence of Streptococcus agalactiae (10.3\%) was detected throughout the sampling period. S. agalactiae was successfully isolated in September (32\%), October (4\%), December (4\%) and March (28\%). Among other bacteria species that were isolated include Aeromonas hydrophila (4.6\%), Staphylococcus spp. (5.1\%) and Plesiomonas shigelloides (1.7\%). Low prevalence (4-12\%) of Cichlidogyrus spp. and Trichodina spp. was also observed during post-mortem. Reverse Transcriptase-Polymerase Chain Reaction (RT-PCR) analysis on all pooled sample of the liver, spleen, and brain showed negative TiLV reaction. This finding suggests that the localized risk in GIFT culture is minimal. However, much attention should be directed to reduce the severity of factors affecting fish health.
\end{abstract}

Keywords: Epidemiology; genetically improved farmed tilapia (gift); streptococcosis; Streptococcus agalactiae; tilapia

ABSTRAK

Penyakit stretokosis, serangan parasit dan jangkitan Tilapia Lake Virus (TiLV) dalam ternakan tilapia telah dilaporkan berlaku di seluruh dunia, menjejaskan pengeluaran tilapia dan mengancam aktiviti akuakultur yang mapan. Maklumat terkini berkaitan kerentangan GIFT terhadap jangkitan stretokosis dan statusnya di Malaysia adalah terhad. Oleh yang demikian, kajian epidemiologi telah dijalankan di ladang ternakan ikan swasta untuk tempoh lapan bulan iaitu dari Ogos 2017 sehingga Mac 2018 untuk menentukan kadar kelaziman jangkitan penyakit bakteria, parasit dan TiLV dalam ternakan sangkar ikan GIFT. Sejumlah 205 ikan GIFT telah diperoleh bagi tujuan pengesanan bakteria, parasitologi dan TiLV. Parameter kualiti air, berat dan panjang ikan, serta tanda-tanda klinikal turut direkodkan sepanjang kajian dijalankan. Secara keseluruhan, kematian ikan GIFT telah direkodkan pada kadar 24.8\% dan kadar kematian yang tinggi telah berlaku dalam tempoh empat bulan ternakan. Kadar jangkitan bakteria Streptococcus agalactiae yang rendah (10.3\%) dikesan sepanjang tempoh persampelan. S. agalactiae telah berjaya dipencilkan pada bulan September (32\%), Oktober (4\%), Disember (4\%) dan Mac (28\%). Antara spesies bakteria lain yang turut dipencilkan adalah Aeromonas hydrophila (4.6\%), Staphylococcus spp. (5.1\%) dan Plesiomonas shigelloides (1.7\%). Kadar jangkitan parasit yang rendah (4-12\%) seperti Cichlidogyrus spp. dan Trichodina spp. turut diperhatikan. Analisis Tindak Balas Rantai Transkripsi-Polimerase Berbalik (RT-PCR) bagi kesemua sampel yang diperoleh menunjukkan reaksi negatif TiLV. Pencirian serotip dan ujian kerentangan antibiotik terhadap strain bakteria S. agalactiae yang telah dipencilkan turut dibincangkan. Hasil kajian menunjukkan bahawa risiko jangkitan stretokosis terhadap ternakan ikan GIFT di lokasi persampelan adalah minimum. Walau bagaimanapun, banyak perhatian harus diarahkan untuk mengurangkan faktor risiko yang mempengaruhi kesihatan ikan.

Kata kunci: Epidemiologi; penambahbaikkan ternakan tilapia (GIFT) secara genetik; stretokosis; Streptococcus agalactiae; tilapia 


\section{INTRODUCTION}

Tilapia (Oreochromis sp.) is a freshwater fish species belonging to the Cichlidae family and native from Africa and southwestern Middle East (Canonico et al. 2005). Tilapia farming in Southeast Asia began to thrive in the 1970s, at present, tilapia is regarded as the most popular culture fish in the world and has been reported being cultured in 126 countries or region (FAO 2015). In Malaysia, tilapias are the second most cultured fish, producing about 32,526.44 metric ton and wholesale value of RM 299.7 million in 2017 (Annual Fisheries Statistics 2017). There are several culture systems adopted for tilapia cultures, which includes a freshwater pond, cages, ex-mining pool, and cement or canvas tank.

One particular strain, Genetically Improved Farmed Tilapia (GIFT), is an outcome from a major research project on genetic improvement of tilapia held by WorldFish Center and collaborators. The project began in 1988, to develop an improved breed of Nile Tilapia (Oreochromis niloticus), to be fast growing and adaptable to a wide range of environments and provide those fish breeds to national testing programs and then to the fish farmers (Ansah et al. 2014). At present, there is twenty generations of GIFT strain that has been produced and distributed to over sixteen countries across five continents including Malaysia.

Initially, it was thought that the fish is more resistant to bacterial, parasitic, and viral diseases compared with other farmed species (Iregui et al. 2014). However, over the past decades it has been shown that tilapias are also susceptible to many bacterial and parasitic diseases. The major bacterial pathogen of tilapia is Streptococcus sp. causing a disease called streptococcosis. To date, two Streptococcus sp. were identified as the most significant etiological agents, which are Streptococcus agalactiae and Streptococcus iniae (Amal \& ZamriSaad 2011). Hasan (2018), in his previous study also reported the infestations of several parasites including Ichthyophthirius multifiliis and Trichodina sp. in GIFT. Recently, tilapia aquaculture industries were threatened by a deadly disease caused by a virus named Tilapia Lake Virus (TiLV), an orthomyxo-like virus belonging to the Orthomyxoviridae family. Reported cases of TiLV are widespread across two continents, Asia and South America, where positive cases were reported in Israel and Equador (in 2014), Colombia, Thailand, and Egypt (in 2017), and Malaysia, India, and Indonesia (in 2018) (Azila et al. 2018; Jansen et al. 2018; Surachetpong et al. 2017).

This on-farm surveillance study was conducted to establish an epidemiological data on diseases of cultured GIFT in Malaysia. The prevalence of Streptococcus sp., Tilapia Lake Virus (TiLV) and parasitic infestation was described in this paper.

\section{MATERIALS AND METHODS}

\section{STUDY SITE AND SAMPLING}

The present study was conducted at a private farm located in Pekan, Pahang Malaysia (East Coast of Peninsular Malaysia). The farm adopted floating net cages culture system and several species of fish including red tilapia, GIFT and Pangasius sp. were routinely cultured. The farm has no recorded history of streptococcosis outbreak. A total of 25 fishes were sampled every month started from August 2017 until March 2018 and subjected to bacteriology and parasitology analysis as well as TiLV detection. The associated clinical signs were carefully observed during the post-mortem, while fish weight, length and mortality were recorded throughout the study period.

\section{BACTERIAL ISOLATION AND IDENTIFICATION}

Sampled of brain, eye and kidney were aseptically streaked onto $5 \%$ sheep blood agar (BA) and incubated at $30 \pm 2{ }^{\circ} \mathrm{C}$ for $24 \mathrm{~h}$. Pure bacterial colonies were subjected to gram staining, oxidase and catalase test, and API rapid identification test. Positive identification of Streptococcus agalactiae and Aeromonas hydrophila were confirmed using Polymerase Chain Reaction (PCR) technique (Amal et al. 2012).

\section{WATER PHYSIOCHEMICAL SAMPLING AND MEASUREMENT}

The water physiochemical parameters include temperature, dissolved oxygen (DO) and $\mathrm{pH}$ were measured from three sampling points within the fish cages. The in situ measurements were made at monthly intervals from (September - March), before the fish sampling activities using a hand-held YSI professional plus (YSI, Yellow Springs, OH, USA).

\section{ECTOPARASITE OBSERVATION}

Gill and body mucus smear were collected from fish and fixed onto clean glass slide by using methanol before stained with Giemsa staining (Martins et al. 2015).

\section{IDENTIFICATION OF TILAPIA LAKE VIRUS (TILV)}

Sample of liver, brain, kidney and spleen obtained from sampling site were preserved in a transport media prior to laboratory analysis. Total nucleic acid was extracted by using taco nucleic acid automatic extractor (GeneReach). The extracted product then subjected to semi-nested reverse transcriptase-polymerase chain reaction (RT-PCR) for TiLV identification (Dong et al. 2017).

\section{SEROTYPING OF Streptococcus agalactiae}

Six isolates of positive identification of Streptococcus agalactiae were subjected to serotyping by using rapid latex agglutination test as per manufacturer's instruction. 
Briefly, an equal quantity of latex reagent (ImmuLex Streptococcus Group B type, SSI Diagnostica) and bacterial culture was mixed on a clean glass slide. Agglutination was observed within $60 \mathrm{~s}$, which indicates a positive reaction.

\section{ANTIBIOTICS SENSITIVITY ASSAY}

Six isolates of positive identification of Streptococcus agalactiae were further subjected to antibiotics sensitivity assay by using disc diffusion method according to Amal et al. (2012) with modifications. Briefly, an overnight culture of $S$. agalactiae was transferred to a tube containing $10 \mathrm{~mL}$ of sterile phosphate buffer saline (PBS). The inoculum density was standardized using 0.5 McFarland standard and swabbed over the entire surface of Mueller Hinton (MH) agar. Commercial antibiotic discs were carefully placed on the agar surface and incubated at $30 \pm 2{ }^{\circ} \mathrm{C}$ for $24 \mathrm{~h}$. Zone diameters around the disc were measured. Antibiotics that were used includes Ampicillin (AMP), Erythromycin (E), Furazolidone (FZ), Oxytetracycline (OT), Cephalothin (CR), Vancomycin (VA), Chloramphenicol (C), Oxolinic acid (OA), Trimethorim sulfamethoxazole (SXT), Streptomycin (S), Kanamycin (K) and Lincomycin (MY). The assay was carried out at least three independent times.

\section{STATISTICAL ANALYSIS}

Calculated data was subjected to Analysis of Variance (ANOVA) with the Tukey HSD all-pairwise comparison tests and Pearson correlation tests using Statistix (Version 10) at $\mathrm{P}=0.05$.

\section{RESULTS AND DISCUSSION}

Tilapia is one of the most farmed aquaculture fish worldwide including Malaysia. The species is considered as hardy, fast growing and able to produce high quality protein from less refined protein sources. Genetically Improved Farmed Tilapia (GIFT) is the product of successful selective breeding program for tropical fish with the aim to produce better breed of tilapia for aquaculture industry. As tested in the laboratory, the strains were previously reported showing superior performance in terms growth and survival when reared in the real environment. A study by Dey et al. (2000), who examined the performance and nature of the GIFT strain in five Asian countries, showed significant increment of $18-53 \%$ body weight at harvest compared to non-GIFT strain in all studied countries, taking into account for the wide heterogeneity of production environments, input levels, and other factors. Performance of the GIFT strain over ten generations of selection (2002-2011) in Malaysia was also previously reported by Azhar et al. (2014), which indicates significant genetic improvement in harvest weight from this population. In the present study, a total of 25 fishes were randomly sampled every month starting from August 2017 until March 2018. The fish body weight was measured as shown in Figure 1(a) and is reflected as GIFT on-farm growth performance. Surprisingly, this study indicated slow increment in fish weight and length of cultured GIFT throughout the sampling period with calculated specific growth rate (SGR) of just $1.4 \%$ per day (Figure 1(a)). It is important to note that no interference has been made in term of the husbandry practices at the farm. As a comparison, the plot of on-farm growth performance of GIFT culture at different location on previous monitoring program in 2016 is summarized in Figure 1(b). This substantial is different in terms of monthly growth of GIFT culture monitoring between the present study and in 2016 suggesting poor husbandry practices at the studied farm.

Streptococcosis is one of the major freshwater fish diseases and is mainly caused by Streptococcus agalactiae or Streptococcus iniae (Amal et al. 2013; Evans et al. 2006). The disease was first reported in 1957 in cultured rainbow trout, Salmo gairdneri in Japan (Hoshina et al. 1958). Since then, the reports of streptococcosis outbreak were increased dramatically to the point of becoming a major threat to the freshwater aquaculture. In Malaysia, streptococosis outbreaks have been continuously reported in floating net cages at Sungai Pahang, Tasik Kenyir, Tasik Pedu and Tasik Pergau since 1999 until present, which leads to the high mortality of cultured tilapia (Amal et al. 2008; Siti-Zahrah et al. 2005). Furthermore, another fish bacterial pathogen such as Aeromonas hydrophila was also reported affecting tilapia farming. Ashraf and Ibrahim (2015) reported an outbreak of $A$. hydrophila in Egypt during the summer season in 2014 that resulted in 30 to $70 \%$ of mortalities among cultured tilapias. In this study, low prevalence of S. agalactiae $(10.3 \%)$ and $A$. hydrophila $(4.6 \%)$ were successfully detected throughout the sampling period. S. agalactiae was isolated in September (32\%), October (4\%), December (4\%), and March (28\%), meanwhile $A$. hydrophila was detected in October (12\%), January (4\%), and March (20\%) as shown in Figure 2. Interestingly, the prevalence of other non-pathogenic bacteria species was high $(76 \%)$ in January, while the prevalence of $S$. agalactiae and $A$. hydrophila were none or minimal. It was believed that the existence of a high population of non-pathogenic bacteria suppressed the population of pathogens as the interactions between bacterial species can profoundly impact the outcome of competition in nature (Hibbing et al. 2010). On the other hand, the cultured GIFT was tested negative to TiLV but was infested with a low prevalence of Trichodina sp. ranged between 8-12\%. Report on trichodiniasis affecting tilapia farming was also previously described elsewhere (Etornyo 2015; Hassan 1999).

At the end of eight month's study period, the fish mortality rate was recorded at $24.8 \%$ from the initial stocking. High mortality was observed in early 4-months 
of culture period from August to November. Mortality in the first month of culture period was associated with transportation stress as the fish (tilapia fry) were transferred from Kedah to Pahang, while high mortality in September and October occurred due to streptococcosis and aeromoniasis where $S$. agalactiae and A. hydrophila were successfully isolated. Several clinical signs have been observed during post-mortem as shown in Figure 3, which includes congested kidney, pale, and patchy liver, enlarged spleen and pop-eye, with 39.4, 20, 9.71, and $2.9 \%$, respectively. There are various risk factors associated with tilapia aquaculture. Among them include elevated water temperatures and deteriorated of other parameter, improper fish handling and lack of farm level biosecurity measures or good management practices (e.g. improper disposal methods of dead fish, overstocking densities in deteriorated water quality and overfeeding).

Thus, it is crucial to understand the interactions between pathogen, host and other risk factors. In this study, we have encountered high mortality in the first month of culture period and unfortunately was associated with elevated stress during transfer of tilapia fry to the cage. Long haul and shipment condition can influence the composition of fish blood. Previous report by Pottinger (2008) indicated that several physiological responses such as release of catecholamines and corticosteroids as well as increased blood glucose level. Various methods of transporting live fishes, consideration factor during transportation and fish stress concept are well documented (Harmon 2009; Omeji et al. 2017; Sampaio \& Freire 2016).

It had been observed in this study that all of the recorded water quality parameters fall within optimal range except in October, February, and March, where the water temperature exceeded $30^{\circ} \mathrm{C}$ and in December, the dissolved oxygen (DO) level was recorded at 3.74 $\mathrm{mg} / \mathrm{mL}$. Furthermore, statistical analysis by using analysis of variance (ANOVA) coupled with Tukey
HSD all-pairwise comparison test indicates that the physiochemical parameters recorded were significantly different between months throughout study period (water temperature, $\mathrm{F}=2065.34, \mathrm{df}=6,29, p<0.05$; dissolved oxygen, $\mathrm{F}=133.03$, df $=6,29, p<0.05 ; \mathrm{pH}, \mathrm{F}=26.58$, $\mathrm{df}=6,29, p<0.05$ ) (Table 1). Conversely, an attempt to associate the prevalence of pathogen and water quality parameter using Pearson correlation test resulted in no significant correlation $(\mathrm{p}>0.05)$. However, recent study conducted by Amal et al. (2015) showed that the presence of $S$. agalactiae has significant correlation with water temperature, clarity, and $\mathrm{pH}$ in lake meanwhile concentration of ammonia, temperature and dissolved oxygen in river.

Six isolates of positive identification of $S$. agalactiae was further characterized in term of serotyping by using latex agglutination test and antibiotic susceptibility assay by using disc diffusion assay against wide selection of antibiotics. S. agalactiae belongs to Group B Streptococcus (GBS) and can be subdivided into 10 different serotypes (Ia, Ib, II to IX) based on the composition of the capsular polysaccharide (Slotved et al. 2007). To the best of our knowledge, only serotype Ia, $\mathrm{Ib}$, and III have been previously reported in fish. Serotype Ia and Ib are the most prevalent in seafood (Van der Mee-Marquet et al. 2009), and Ia, Ib, and III are the most common serotypes isolated from infected tilapia (Rodkhum et al. 2011). Serotype III has four subtypes and recently the subtype 4 has been described as an emergent pathogen in fish farms in Thailand and China (Delannoy et al. 2013; $\mathrm{Li}$ et al. 2013). In the present study, all of these isolates were characterized as serotype III. This is in accordance with previous finding by Suphia-Amiera et al. (2016) that indicated all local isolates tested are belong to Group B Type III. Worryingly, during the experimental challenge, serotype III showed much higher virulence than serotype Ia and Ib (Kannika et al. 2017), which might be due to higher ability in biofilm formation.

(a)

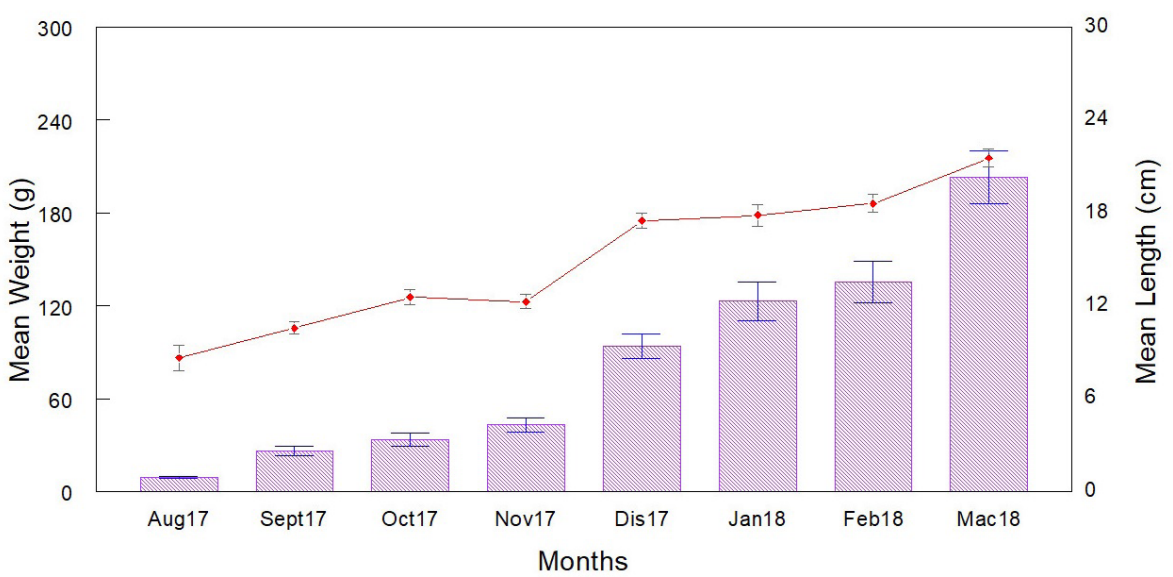




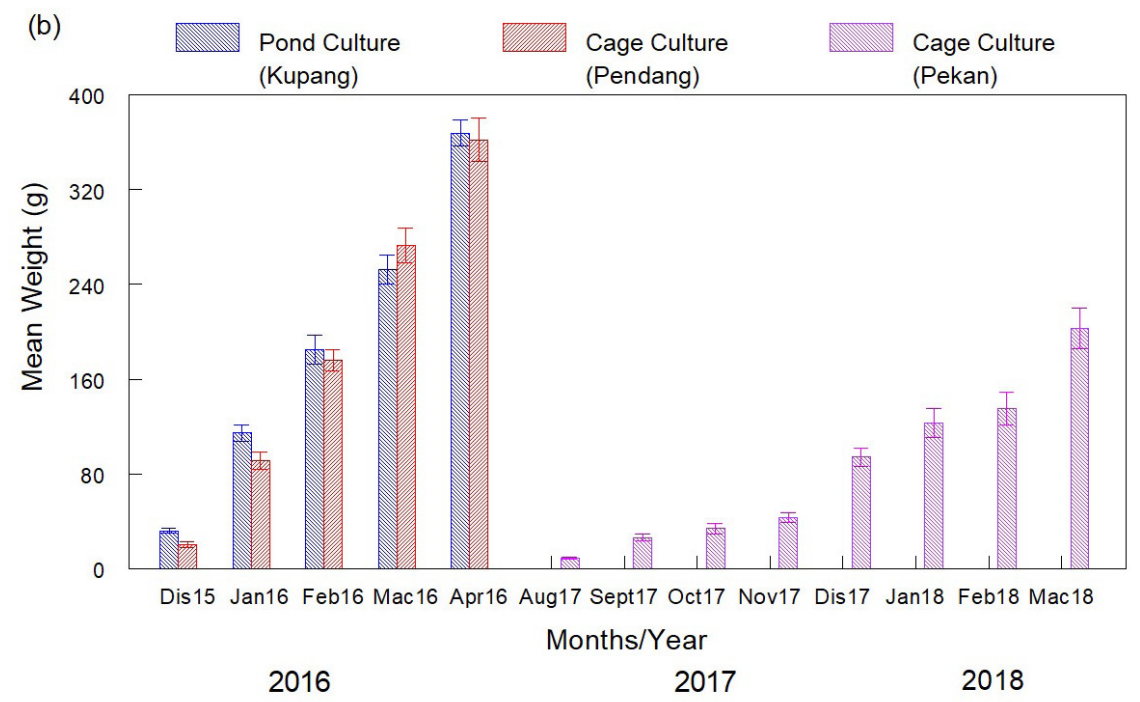

FIGURE 1. (a) Monthly growth of GIFT during eight months of culture period (b) Comparative growth performance of GIFT culture from different location in 2016-2018. Substantial different of monthly growth of GIFT culture was noted thus suggesting problem with husbandry practices

Antibiotics susceptibility assay of these six isolates were determined against a wide selection of antibiotics and the resulted zone of inhibition diameter was summarized as in Table 2. All strains were found resistant against Furazolidone (Nitrofuran antibacterial agent), Oxolinic acid (Quinolone), Streptomycin (Aminoglycosides) and
Kanamycin (Aminoglycosides). However, similar resistant phenotypes of $S$. agalactiae were formerly reported in Golden pompano culture in Malaysia (Amal et al. 2012). Thus, we believed that the major part of these multiresistance features might be intrinsic to the local isolates without being a result of antibiotic drug used in the farm.

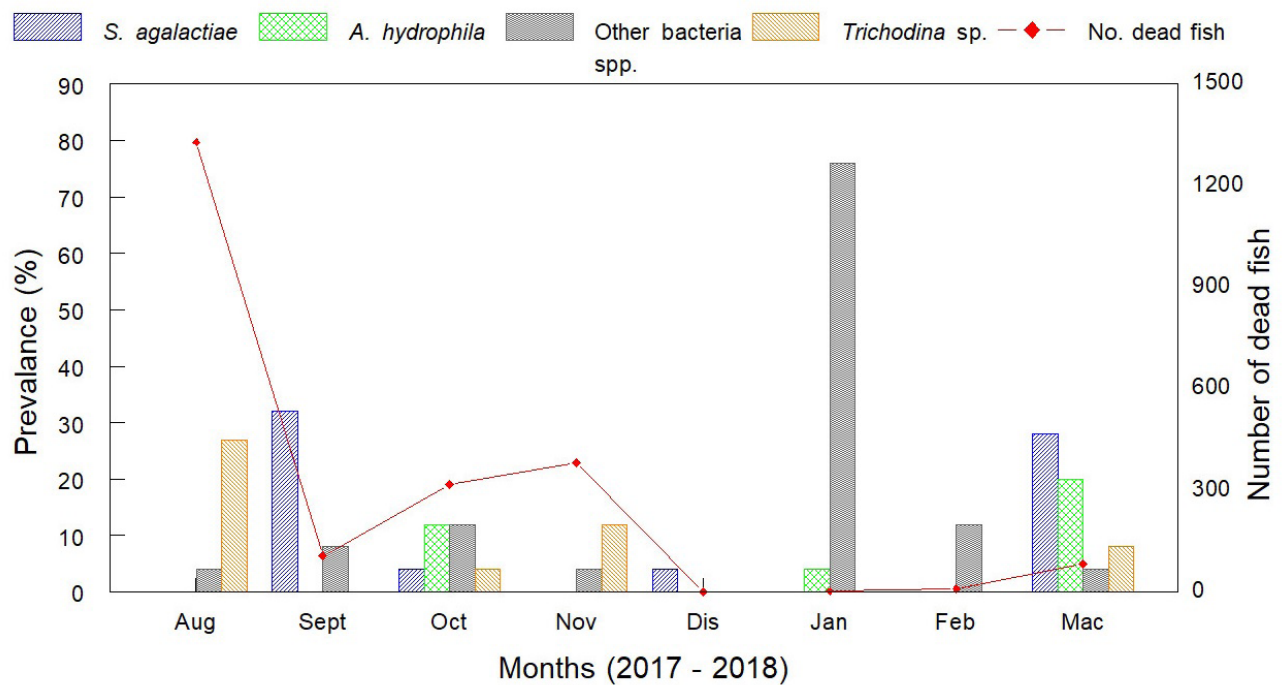

FIGURE 2. Monthly isolation pattern of Streptococcus agalactiae, Aeromonas hydrophila and other bacteria species, and Trichodina sp. 


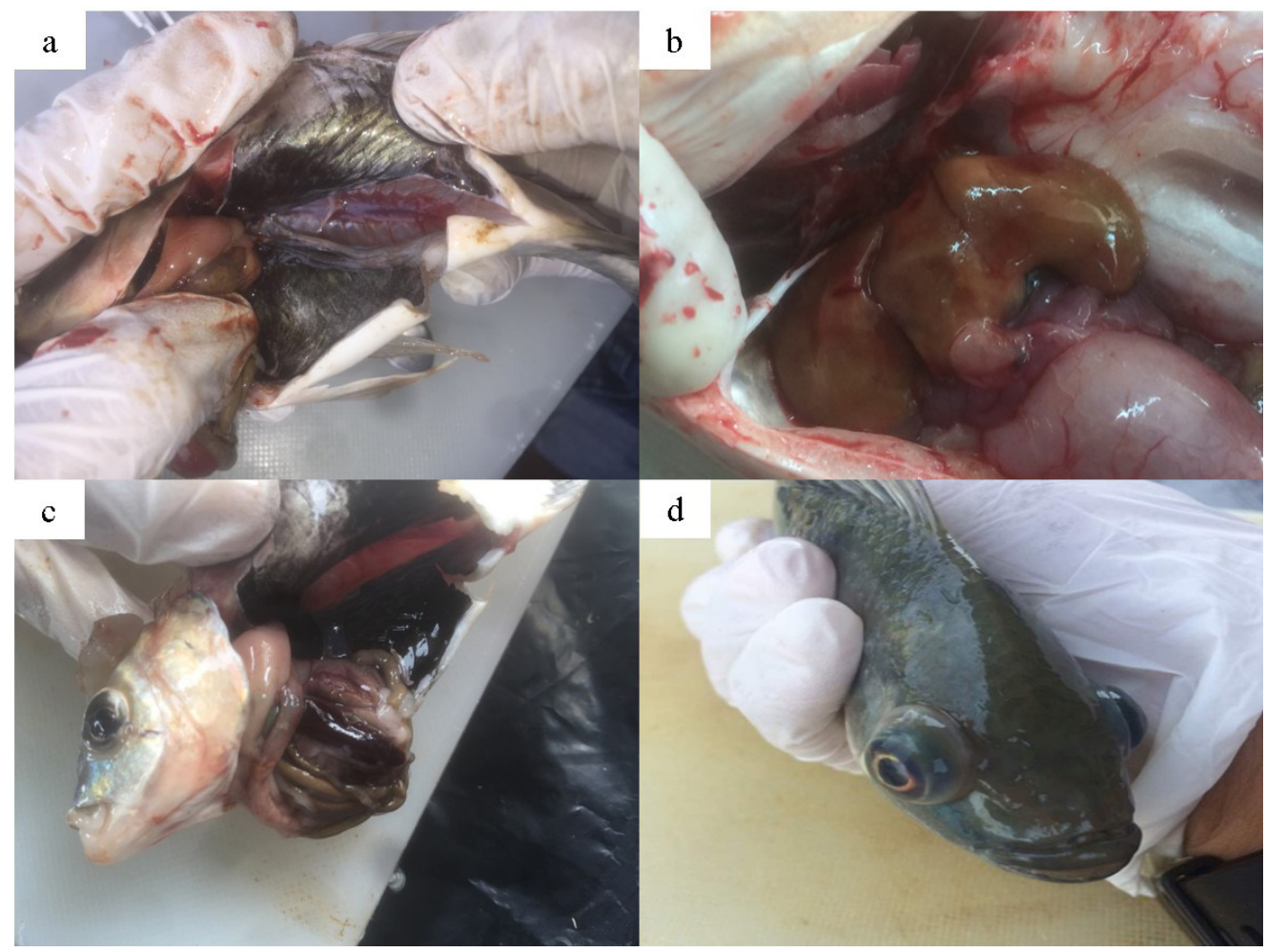

FIGURE 3. Clinical signs observed in diseased fish during field sampling (a)

Congested kidney (b) Pale and patchy liver (c) Enlarged spleen, and (d) Pop-eye

TABLE 1 . Recorded water quality parameters throughout study period

\begin{tabular}{|c|c|c|c|c|c|c|}
\hline \multirow{2}{*}{ Month } & \multicolumn{2}{|c|}{ Temperature $\left({ }^{\circ} \mathrm{C}\right)$} & \multicolumn{2}{|c|}{ Dissolved oxygen $\left(\mathrm{mg} \mathrm{L}^{-1}\right)$} & \multicolumn{2}{|c|}{$\mathrm{pH}(1-14)$} \\
\hline & Mean \pm SD & Range & Mean \pm SD & Range & Mean \pm SD & Range \\
\hline September & $29.90 \pm 0.00^{\mathrm{a}}$ & 29.90 & $4.16 \pm 0.18^{\mathrm{a}}$ & $4.03-4.28$ & $6.34 \pm 0.08^{\mathrm{a}}$ & $6.40-6.28$ \\
\hline October & $31.50 \pm 0.00^{\mathrm{b}}$ & 31.50 & $8.46 \pm 0.69^{\mathrm{a}}$ & $7.28-9.24$ & $6.90 \pm 0.31^{\mathrm{a}}$ & $6.37-7.13$ \\
\hline November & $27.22 \pm 0.08^{b}$ & $27.10-27.30$ & $4.01 \pm 0.14^{\mathrm{a}}$ & $3.84-4.20$ & $6.37 \pm 0.33^{\mathrm{a}}$ & $5.81-6.78$ \\
\hline December & $27.73 \pm 0.05^{\mathrm{c}}$ & $27.70-27.80$ & $3.74 \pm 0.34^{\mathrm{ab}}$ & $3.25-4.18$ & $7.22 \pm 0.06^{\mathrm{ab}}$ & $7.17-7.33$ \\
\hline January & $27.10 \pm 0.00^{\mathrm{cd}}$ & 27.10 & $4.62 \pm 0.12^{\mathrm{b}}$ & $4.42-4.77$ & $7.46 \pm 0.19^{b}$ & $7.30-7.82$ \\
\hline February & $30.50 \pm 0.00^{\mathrm{cd}}$ & 30.50 & $5.92 \pm 0.11^{\mathrm{c}}$ & $5.80-6.03$ & $7.36 \pm 0.12^{\mathrm{c}}$ & $7.23-7.50$ \\
\hline Mac & $31.30 \pm 0.23^{\mathrm{d}}$ & $31.00-31.50$ & $6.10 \pm 0.24^{c}$ & $5.79-6.47$ & $7.59 \pm 0.11^{\mathrm{c}}$ & $7.72-7.41$ \\
\hline
\end{tabular}

Comparison between mean $\pm \mathrm{SD}$ along the same column. Values with different superscript letter are significantly difference at $\mathrm{p}<0.05$ 
TABLE 2. The inhibition zone diameter ( $\mathrm{mm}$ ) of six confirmed isolates of S. agalactiae against wide selection of antibiotics. Data are presented as means \pm SEM

\begin{tabular}{|c|c|c|c|c|c|c|c|c|c|c|c|c|}
\hline $\begin{array}{l}\text { Strain } \\
\text { id }\end{array}$ & AMP25 & Int. ${ }^{1}$ & E30 & Int. $^{1}$ & FZ100 & Int. $^{2}$ & OT30 & Int. $^{3}$ & CR30 & Int. $^{2}$ & VA30 & Int. ${ }^{4}$ \\
\hline TP162 & $29.5 \pm 3.5$ & S & $33.5 \pm 1.25$ & INT & 0 & $\mathrm{R}$ & $25.0 \pm 2.0$ & INT & $29.0 \pm 0.0$ & $\mathrm{~S}$ & $23.0 \pm 0.0$ & S \\
\hline TP163 & $39.0 \pm 4.0$ & S & $32.5 \pm 1.25$ & INT & 0 & $\mathrm{R}$ & $23.0 \pm 1.0$ & INT & $33.5 \pm 3.5$ & $\mathrm{~S}$ & $23.5 \pm 1.5$ & S \\
\hline TP164 & $36.5 \pm 6.5$ & S & $33.5 \pm 1.25$ & INT & 0 & $\mathrm{R}$ & $23.0 \pm 2.0$ & INT & $26.5 \pm 3.5$ & $\mathrm{~S}$ & $22.5 \pm 1.5$ & S \\
\hline TP168 & $38.5 \pm 6.5$ & S & $33.5 \pm 0.75$ & INT & 0 & $\mathrm{R}$ & $26.5 \pm 3.5$ & S & $31.0 \pm 0.0$ & S & $24.0 \pm 0.0$ & S \\
\hline ТP169 & $41 \pm 0.5$ & S & $30.5 \pm 0.75$ & INT & 0 & $\mathrm{R}$ & $23.5 \pm 1.5$ & INT & $30.5 \pm 0.5$ & S & $23.0 \pm 0.0$ & S \\
\hline ТP170 & $39.5 \pm 2.5$ & $\mathrm{~S}$ & $30.0 \pm 0.0$ & INT & 0 & $\mathrm{R}$ & $24.0 \pm 2.0$ & INT & $31.0 \pm 0.0$ & $\mathrm{~S}$ & $23.5 \pm 0.5$ & $\mathrm{~S}$ \\
\hline $\begin{array}{l}\text { Strain } \\
\text { id }\end{array}$ & $\mathrm{C} 30$ & Int. $^{4}$ & OA2 & Int. $^{4}$ & SXT25 & Int. $^{4}$ & S10 & Int. $^{4}$ & K30 & Int. $^{4}$ & MY15 & Int. $^{5}$ \\
\hline TP162 & $28.5 \pm 1.5$ & S & 0 & INT & $22.0 \pm 1.0$ & S & 0 & $\mathrm{R}$ & 0 & $\mathrm{R}$ & $30.5 \pm 0.5$ & S \\
\hline TP163 & $29.0 \pm 0.0$ & S & 0 & INT & $23.0 \pm 0.0$ & S & 0 & $\mathrm{R}$ & 0 & $\mathrm{R}$ & $30.0 \pm 2.0$ & $\mathrm{~S}$ \\
\hline TP164 & $29.0 \pm 2.0$ & $\mathrm{~S}$ & 0 & INT & $21.5 \pm 0.5$ & S & 0 & $\mathrm{R}$ & 0 & $\mathrm{R}$ & $29.0 \pm 3.0$ & S \\
\hline TP168 & $31.0 \pm 3.0$ & S & 0 & INT & $25.0 \pm 0.0$ & S & 0 & $\mathrm{R}$ & 0 & $\mathrm{R}$ & $31.0 \pm 2.0$ & S \\
\hline ТP169 & $29.5 \pm 2.5$ & S & 0 & INT & $22.0 \pm 1.0$ & S & 0 & $\mathrm{R}$ & 0 & $\mathrm{R}$ & $30.5 \pm 2.5$ & S \\
\hline ТР170 & $27.5 \pm 0.5$ & $\mathrm{~S}$ & 0 & INT & $20.5 \pm 2.5$ & $\mathrm{~S}$ & 0 & $\mathrm{R}$ & 0 & $\mathrm{R}$ & $29.5 \pm 2.5$ & S \\
\hline
\end{tabular}

${ }^{1}$ Based on Andrews (2009). ${ }^{2}$ Based on (Atlas Medical, 2005) the antibiotic sensitivity discs leaflet. ${ }^{3}$ Based on (Vetlab Supply, 2011). ${ }^{4}$ Based on (Clinical and Laboratory Standards Institute (CLSI), 2013). ${ }^{5}$ Based on (Sigma-Aldrich, n.d.). Ampicillin (AMP); Erythromycin (E); Furazolidone (Fz), Oxytetracycline (OT), Cephalothin (Cr), Vancomycin (Va), Chloramphenicol (C), Oxolinic acid (OA) Trimethorim Sulfamethoxazole (SXT), Kanamycin (K), Lincomycin (MY), Streptomycin (S)

\section{CONCLUSION}

This finding suggested that the localized risk of Streptococcus sp. infection, TiLV, and parasitic infestation in GIFT culture is minimal. However, much attention should be directed to reduce the severity of factors affecting fish health. The establishment of good husbandry practices and implementation of bio-security measures at all culture stages is recommended.

\section{ACKNOWLEDGEMENTS}

This work was supported by the Department of Fisheries Malaysia (DOF) Development Fund (P21225010390001: Research on aquaculture fish disease \& vaccine development/diagnosis kit). The authors appreciate full cooperation from Mr. Yahya (farm supervisor) and support from District Fisheries Office of Pekan, Pahang. CVM was supported by the CGIAR Research Program on Fish AgriFood Systems (FISH) led by WorldFish.

\section{REFERENCES}

Amal, M.N.A. \& Zamri-Saad, M. 2011. Streptococcosis in Tilapia (Oreochromis niloticus): A review. Pertanika Journal of Agricultural Sciences 34(2): 195-206.

Amal, M.N.A., Zamri-Saad, M., Siti-Zahrah, A. \& Zulkafli, A.R. 2015. Water quality influences the presence of Streptococcus agalactiae in cage cultured red hybrid tilapia, Oreochromis niloticus x Oreochromis mossambicus. Aquaculture Research 46(2): 313-323.

Amal, M.N.A., Zamri-Saad, M., Siti-Zahrah, A., Zulkafli, A.R. \& Nur-Nazifah, M. 2013. Molecular characterization of Streptococcus agalactiae strains isolated from fishes in Malaysia. Journal of Applied Microbiology 115(1): 20-29.

Amal, M.N.A., Zamri-Saad, M., Iftikhar, A.R., Siti-Zahrah, A., Aziel, S. \& Fahmi, S. 2012. An outbreak of Streptococcus 
agalactiae infection in cage-cultured golden pompano, Tranchinotus blochii (Lacepede), in Malaysia. Journal of Fish Diseases 35(11): 849-852.

Amal, A.M.N., Siti-Zahrah, A., Zulkafli, R., Misri, S., Ramley, A. \& Zamri-Saad, M. 2008. The effect of water temperature on the incidence of Streptococcus agalactiae infection in cage-cultured tilapia. International Seminar on Management Strategies on Animal Health and Production Control in Anticipation of Global Warming. pp. 48-51.

Andrews, J.M. 2009. British society for antimicrobial chemotherapy (BSAC) standardized disc susceptibility testing method (version 8). Journal of Antimicrobial Chemotherapy 64(3): 454-489.

Ansah, Y.B., Frimpong, E.A. \& Hallerman, E.M. 2014. Genetically-improved tilapia strains in Africa: Potential benefit and negative impacts. Sustainability 6: 3697-3721.

Ashraf, G. \& Ibrahim, A. 2015. Molecular detection of Aeromonas hydrophila as the main cause of outbreak in tilapia farm in Egypt. Journal of Aquaculture \& Marine Biology 2(6): 45-48.

Atlas Medical. 2005. The Antibiotic Sensitivity Discs. http:// atlas- medical.com/product/212/Antibiotic-Discs-Kits. Accessed on 19 February 2017.

Azhar, H., Ponzoni, R., Nguyen, N., Khaw, H.L., Yip, Y.H. \& Siti-Azizah, M. 2014. Genetic evaluation of the genetically improved farmed tilapia (GIFT) strain over ten generations of selection in Malaysia. Pertanika Journal of Tropical Agricultural Science 37(4): 411-429.

Azila, A., Rimatulhana, R., Mohd-Syafiq, M.R., Fahmi, S., Adnan, A., Kamisa, A., Munira, M. \& Kua, B.C. 2018. First detection of tilapia lake virus (TiLV) in wild river carp (Barbonymus schwanenfeldii) at Timah Tasoh Lake, Malaysia, Journal of Fish Diseases 41(1): 1-4.

Canonico, G.C., Arthington, A., Mccrary, J.K. \& Thieme, M.L. 2005. The effect of introduced tilapias on native biodiversity. Aquatic Conservation: Marine and Freshwater Ecosystem 15(5): 463-483.

Clinical and Laboratory Standards Institute (CLSI). 2013. Performance Standards for Antimicrobial Susceptibility Testing; 23 Informational Supplement. CLSI document M100-S23 (ISBN 1-56238-865-7), Pennsylvania, USA. https://www.facm.ucl.ac.be. Accessed on 5 December 2014.

Delannoy, C.M.J., Crumlish, M., Fontaine, M.C., Pollock, J., Foster, G., Dagleish, M.P., Turnbull, J.F. \& Zadoks, R.N. 2013. Human Streptococcus agalactiae in aquatic mammals and fish. BMC Microbiology 13: 41.

Department of Fisheries Malaysia. 2017. Annual Fisheries Statistic.

Dey, M.M., Eknath, A.E., Sifa, L., Hussain, M.G., Thien, T.M., Nguyen, V.H., Aypa, S. \& Pongthana, N. 2000. Performance and nature of genetically improved farmed tilapia: A bioeconomic analysis. Journal Aquaculture Economics \& Management 4(1-2): 83-106.

Etornyo, A. 2015. Ecto-parasite infestation of Nile Tilapia (Oreochromis niloticus) in concrete pond in Tamale, Ghana. International Journal of Aquaculture 5(4): 1-5.

Evans, J.J., Klesius, P.H. \& Shoemaker, C.A. 2006. An overview of Streptococcous in warm water fish. Aquaculture Health International 7: 10-14.

Food and Agriculture Organization of the United Nation (FAO). 2015. World Aquaculture 2015: A Brief Overview
(FAO Circular No. 1140). https://www.fao.org/3/a-i7546e. Accessed on 7 June 2017.

Harmon, T.S. 2009. Methods for reducing stressors and maintaining water quality associated with live fish transport in tanks: A review of the basics. Reviews in Aquaculture 1(1): 58-66

Hassan El-Azez, A.H. 1999. Trichodiniasis in farmed freshwater tilapia in Eastern Saudi Arabia. Journal of King Abdulaziz University - Marine Sciences 10: 157-168.

Hibbing, M.E., Fuqua, C., Parsek, M.R. \& Peterson, S.B. 2010. Bacterial competition: Surviving and thriving in the microbial jungle. Nature Review Microbiology 8(1): 15-25.

Hoshina, T., Sano, T. \& Morimoto, Y. 1958. A Streptococcus pathogenic to fish. Journal of the Tokyo University of Fisheries 44: 57-58.

Iregui, C., Barato, P., Rey, A., Vasquez, G. \& Verjan, N. 2014. Epidemiology of Streptococcus agalactiae and streptococcosis in tilapia fish. In Epidemiology 1: Theory, Research and Practice. Hong Kong: iConcept Press. pp. 251-268.

Jansen, M.D., Dong, H.T. \& Mohan, C.V. 2018. Tilapia lake virus: A threat to the global tilapia industry. Reviews in Aquaculture 11(3): 1-15.

Kannika, K., Pisuttharachai, D., Srisapoome, P., Wongtavatchai, J., Kondo, H., Hirono, I., Unajak, S. \& Areechon, N. 2017. Molecular serotyping, virulence gene profiling and pathogenicity of Streptococcus agalactiae isolated from tilapia farms in Thailand by multiplex PCR. Journal of Applied Microbiology 166(6): 1497-1507.

Li, L., Wang, R., Liang, W., Gan, X., Huang, T., Huang, Y., Li, J., Shi, Y., Chen, M. \& Luo, H. 2013. Rare serotype occurrence and PFGE genotyping diversity of Streptococcus agalactiae isolated from tilapia in China. Veterinary Microbiology 167(3-4): 719-724.

Martins, M.L., Cardoso, L., Marchiori, N. \& de Padua S.B. 2015. Protozoan infections in farmed fish from Brazil: Diagnosis and pathogenesis. Revista Brasileira de Parasitologia Veterinaria 24(1): 1-20.

Omeji, S., Apochi, J.O. \& Egwumah, K.A. 2017. Stress concept in transportation if live fishes - a review. Journal of Research in Forestry, Wildlife \& Environment 9(2): 57-64.

Pottinger, T.G. 2008. The stress response in fish-mechanism, effects and measurement. In Fish Welfare, edited by Branson, E.J. New Jersey: Wiley-Blackwell. pp. 32-48.

Rodkhum, C., Kayansamruaj, P. \& Pirarat, N. 2011. Effect of water temperature on susceptibility to Streptococcus agalactiae serotype Ia infection in Nile Tilapia (Oreochromis niloticus). The Thailand Journal of Veterinary Medicine 41(3): 309-314.

Sampaio, F.D.F. \& Freire, C.A. 2016. An overview of stress physiology of fish transport: Changes in water quality as a function of transport duration. Fish and Fisheries 17(4): $1055-1072$

Sigma-Aldrich. (n.d.). Antimicrobial Susceptibility Discs. https:// www.sigmaaldrich.com.

Siti-Zahrah, A., Padilah, B., Azila, A., Rimatulhana, R. \& Shahidan, H. 2005. Multiple Streptococcal species infection in cage-cultured red tilapia but showing similar clinical signs. Sixth Symposium on Diseases in Asian Aquaculture. pp. 332-339. 
Slotved, H.C., Kong, F., Lamberstsen, L., Sauer, S. \& Gilbert, G.L. 2007. Serotype IX, a proposed new Streptococcus agalactiae serotype. Journal of Clinical Microbiology 45(9): 2929-2936.

Surachetpong, W., Janetanakit, T., Nonthabenjawan, N., Tattiyapong, P., Sirikanchana, K. \& Amonsin, A. 2017. Outbreaks of Tilapia Lake Virus Infection, Thailand, 20152016. Emerging Infectious Diseases 23(6): 1031-1033.

Van der Mee-Marquet, N., Domelier, A.S., Salloum, M., Violette, J., Arnault, L., Gaillard, N., Bind, J.L., Lartigue, M.F. \& Quentin, R. 2009. Molecular characterization of temporally and geographically matched Streptococcus agalactiae strains isolated from food products and bloodstream infections. Foodborne Pathogen and Disease 6(10): 1177-1183.

Vetlab Supply. 2011. Antimicrobial Disk Diffusion Zone Interpretation Guide. http://www.vetlab.com/Antibiotic\%20 Susceptibility\%20Testing.htm. Accessed on 1 January 2011.
Chadag Vishnumurthy Mohan

WorldFish

11960 Batu Maung, Pulau Pinang

Malaysia

Mohd Firdaus Nawi

Department of Marine Science

Kulliyyah of Science

International Islamic University Malaysia

Bandar Indera Mahkota

25200 Kuantan, Pahang Darul Makmur

Malaysia

*Corresponding author; email: syafiq@dof.gov.my

Received: 29 August 2019

Accepted: 5 April 2020

Mohd Syafiq Mohammad Ridzuan*, Nur Amirah Md Radzi, Fahmi Sudirwan, Kamisa Ahmad \& Kua Beng Chu

National Fish Health Research Division (NaFisH)

Fisheries Research Institute (FRI) Batu Maung

Department of Fisheries Malaysia

11960 Batu Maung, Pulau Pinang

Malaysia 